The importance of individual works and cooperation of higher education and secondary education institutions in improving the quality of Arabic language teaching /M. Öztürk (pp. 898-914)

\title{
56-Arapça eğitim kalitesinin artırılmasında yükseköğretim ve ortaöğretim kurumlarının bireysel ve ortaklaşa yapacakları çalışmaların önemi
}

Mevlüt ÖZTÜRK1

\begin{abstract}
APA: Öztürk, M. (2020). Arapça eğitim kalitesinin artırılmasında yükseköğretim ve ortaöğretim kurumlarının bireysel ve ortaklaşa yapacakları çalışmaların önemi. RumeliDE Dil ve Edebiyat Araştırmaları Dergisi, (21), 898-914. DOI: 10.29000/rumelide.843351.
\end{abstract}

\section{$\ddot{O} \mathbf{z}$}

Ülkemizde Arapça eğitimi lise düzeyinde imam-hatip liselerinde, yükseköğretim düzeyinde resmî ve özel yükseköğretim kurumlarında gerçekleşmektedir. Yükseköğretim kurumlarımızda Arapça eğitimi "İlahiyat ve İslami İlimler Fakülteleri”, "Yabancı Diller Yüksekokulları”, "Arap Dili ve Edebiyatı Bölümü ve Arap Dili Eğitimi Bölümleri”nce verilmektedir. İmam-hatip liselerinde ve lise sonrası yükseköğretimde Arapça eğitimi gören öğrencilerin hazırbulunuşluklarının ve eğitim kalitelerinin artırılması büyük bir önem arzetmektedir. Bunun içinde öğrencilerin Arapçaya karşı tutumlarının belirlenmesine yönelik çalışmalara, eğitim programının belirlenmesinde öncü olan metot ve tekniklere, bu programların uygulanabilmesinde kullanılan araç gereçlere, bu eğitimi gerçekleştiren eğitimciye, uygun ölçme-değerlendirme araçlarından öğrenenin motive edilmesine kadar süreç ile ilgili bir dizi çalışmalar yapılmış ve bu çalışmalara yenileri eklenerek yapılmaya devam etmektedir. Ortaöğretim ve yükseköğretim kurumlarımızda yapılan Arapça eğitimlerinde, eğitim kalitesinin artırılması için her iki kurumun kendi bünyesinde yaptıkları çalışmaların yanında bu kurumların ortaklaşa çalışmalar da yapması gerekmektedir. Çalışmada eğitim kalitesinin artırılmasında ortaöğretim ve yükseköğretim kurumlarının bireysel olarak yapmaları gerekli çalışmalar ile ortak çalışmaların neler olduğu, bu tür çalışmaların gerekliliği ve böyle bir çalışmanın her iki kurumdaki Arapça eğitimine katkıları ortaya konulmak istenmiştir.

Anahtar kelimeler: Arap dili eğitimi, yükseköğretim, ortaöğretim, İmam Hatip Liseleri, Arapça öğretim programı

\section{The importance of individual works and cooperation of higher education and secondary education institutions in improving the quality of Arabic language teaching}

\begin{abstract}
In our country, Arabic language teaching takes place at high school level in imam-hatip high schools, at higher education level in official and private higher education institutions. In our higher education institutions, Arabic is thought by "Faculties of Theology and Islamic Sciences", "Schools of Foreign Languages", "Department of Arabic Language and Literature and Departments of Arabic Language Education". It is of great importance to increase the readiness and improve educational quality of the students studying Arabic in Imam-hatip high schools and highe reducation following the high school. For this purpose, a series of studies have been conducted on the process covering the studies aiming to determine students' attitudes towards Arabic, the leading methods and techniques in determining the cirriculum, the tools used in the implementation of the cirriculum,
\end{abstract}

Dr. Öğr. Üyesi, Necmettin Erbakan Üniversitesi, Ahmet Kelesoğlu Eğitim Fakütesi, Yabancı Diller Bölümü, Arap Dili Eğitimi ABD (Konya, Türkiye), ozturk.mevlut@hotmail.com, ORCID ID: oooo-0oo2-5711-520X [Araştırma makalesi, Makale kayıt tarihi: 10.11.2020-kabul tarihi: 20.12.2020; DOI: 10.2900o/rumelide.843351]

Adres
Address

Istanbul Medeniyet University, Faculty of Education Sciences,

Turkish and Social Scinces Education, Turkish Language Teaching

Education, Cevizli Campus, Kartal-İstanbul /TURKEY

e-mail: editor@rumelide.com 
the educators who performs the educational activities, the appropriate assessment-evaluation tools and the motivation of the learner and those studies continue to be conducted by adding new ones. In order to improve the quality of education in Arabic language teaching in our secondary and higher education institutions, these institutions should also work in cooperation in addition to the individual works by both institutions. In this study, it was aimed to reveal what secondary education and higher education institutions should do individually and in cooperation in order to increase the quality of education, the necessity of such studies and the contributions of such a study to Arabic language teaching in both institutions.

Keywords:Arabic language teaching, higher education, secondary education, İmam Hatip High Schools, Arabic language cirriculum

\section{Giriş}

\section{1.Çalışmanın amacı}

Çalışmada Arapça eğitim kalitesinin artırılmasında ortaöğretim ve yükseköğretim kurumlarının yapmaları gerekli olan çalışmaları ile birlikte yapacakları ortak çalışmaların neler olduğu, bunun gerekliliği ve böyle bir çalışmanın her iki kurumdaki Arapça eğitimine katkılarının faydaları ortaya konulmak istenmiştir.

\section{2. Çalışmanın konusu}

Arapça eğitimi, eğitim sistemimizde temel öğretimde imam hatip ortaokullarında, ortaöğretim seviyesinde imam-hatip liselerinde ve yükseköğretimde ise, "İlahiyat ve İslami İlimler Fakülteleri”, "Yabancı Diller Yüksekokulları”, “Arap Dili ve Edebiyatı Bölümü ve Arap Dili Eğitimi Bölümleri”nce verilmektedir.

Çalışmada öncelikli olarak eğitimin uygulandığı mevcut programların analizi yapılarak karşılaştırılmış ve değerlendirilmiştir. Araştırma ortaöğretim kurumları ve yükseköğretim kurumlarındaki Arapça eğitimi ile ilgili çalışmalar ile sınırlandırılmıştır. Bu nedenle de imam-hatip liseleri ve bu liselerin dışında yeralan ortaöğretim kurumlarındaki Arapça eğitiminin durumu üzerinde çalışma yapılmıştır. İmam hatip ortaokullarındaki Arapça eğitimine bu çalışmada sadece bu kurumlarla ilgili olan durumlarda değinilmiştir. Çalışmada aşağıdaki konu başlıklarına yer verilmiştir:

1. Anadolu İmam Hatip Liselerinde Arapça öğretimi ve Anadolu İmam Hatip Lisesi Arapça Dersinin Öğretim Programının genel özellikleri,

2. Yükseköğretim Kurumlarında Arapça öğretimi ve Arapça öğretimi Programının genel özellikleri,

3. Anadolu İmam Hatip Lisesi Arapça Dersinin Öğretim Programı ile Yükseköğretim Kurumlarında Arapça Eğitiminin Programının karşılaştırılması,

4. Anadolu İmam Hatip Liseleri dışındaki ortaöğretim kurumlarındaki Arapça öğretiminin durumu,

5.Arapça Eğitim sonunda ulaşlan amaçların istenilen seviyede bulunmamasının nedenleri ve bu sorunun çözümündeki öneriler.

Adres

İstanbul Medeniyet Üniversitesi, Eğitim Bilimleri Fakültesi, Türkçe ve Sosyal Bilimler Eğitimi Bölümü, Türkce Eğitimi ABD Cevizli Kampüsü, Kartal-İstanbul/TÜRKIYE e-posta: editor@rumelide.com 


\section{3. Çalışmanın metodu}

Çalışmada Arapça eğitimi ve Arapça eğitiminde kalitenin artırılması için yapılan bilimsel araştırmalar literatür taraması şeklinde çok boyutlu bir şekilde incelenmiş, bu bilimsel çalışmalar ışı̆̆ında da yukarıda verilen alt konu başlıkları sırası ile incelenerek sonuca varılmak istenmiştir. Sonuç ve değerlendirmeden sonra araştırmanın amacı, Arapça eğitim kalitesinin artırılmasında ortaöğretim ve yükseköğretim kurumlarının bireysel çalışmalarının yanında ne tür ortak çalışmalar yapmaları gerektiği konusunda önerilerde bulunulmuştur.

\section{4. Çalışmada yer verilen konu başlıkları}

\subsubsection{Anadolu İmam Hatip Liselerinde Arapça öğretimi ve Anadolu İmam Hatip Lisesi Arapça dersinin öğretim programının genel özellikleri}

Anadolu imam hatip liseleri mezunları, günümüzde yükseköğretimde sayısal, eşit ağırlık ve sözel programlarda öğretim yapan farklı bölümleri tercih edebilmektedirler. İmam-hatip liselerinden mezun olan öğrencilerden bir kısmı, bu liselerin yükseköğretimdeki devamı niteliğinde gördükleri ilahiyat ve İslami ilimler fakültelerinde öğrenim görmek istemektedirler.

Son yıllarda yükseköğretimde Arapça dersinin okutulduğu ve Arapça eğitimin yapıldığı Arap dili ve edebiyatı, Arapça öğretmenliği, mütercim tercümanlık gibi bölümlere girmek için ÖSYM'nin yaptığı "Yükseköğretim Kurumları Sınavı" bünyesinde bulunan "Yabancı Dil Sınavı"nda adaylara Arapça sorularının sorulması neticesinde imam hatip liseleri mezunları bu bölümlere de yönelmişlerdir.

$\mathrm{Bu}$ nedenle lise eğitimleri sonrasında Arapça eğitimine dayalı lisans eğitiminde birçok seçenekle karşlaşan imam hatip lisesi öğrencilerinin son yıllarda Arapça öğretimine büyük bir ilgi gösterdikleri görülmektedir.

Milli Eğitim Bakanlığı Din Öğretimi Genel Müdürlüğü bu liselerin müfredatında bulunan Arapça derslerinin yanında Arapça dil proje okulları ve dil proje sınıfları da oluşturarak öğrencilerden gelen istekleri karşıladığı gibi, Milli Eğitim Bakanlığının öğrencilerin birden fazla yabancı dil öğrenmesi amacında olduğu yeni vizyonuna uygun olan bir yapılanma içerisinde bulunmaktadır.

Bakanlık, imam hatip ortaokullarında ve liselerinde yaptığı norm kadro işlemlerinde Arapça öğretmenleri ile imam hatip meslek dersleri ve din kültürü ve ahlak bilgisi öğretmenlerinin okutacakları ders alanlarını yeniden belirleyerek Arapça dersi için farklı bir öğretmen norm kadrosu vermiştir. Bu uygulama, Bakanlık’ın Arapça öğretiminin uzmanlaşması konusuna verdiği önemi göstermektedir.

İmam hatip liselerinde Arapça eğitimindeki kaliteyi artırmak için yine Bakanlık, farklı paydaşlar ile işbirliği yaparak elde edilen bilimsel çalışmalar neticesinde başta müfredat olmak üzere Arapça eğitiminde bir yapılanma içerisine girmiştir. Bakanlık; akademisyenler, uzmanlar ve bu eğitimi fiili olarak uygulayan öğretmenlerin katılımı ile bir müfredat oluşturmuştur. Oluşturulan bu müfredatta Arapça eğitiminde öğrenci merkezli bir öğrenme benimsenmiş ve buna uygun vizyon açıç̧a ortaya konmuş, bu vizyona uygun hedef-davranışlar ve kazanımları ifade edilmiştir.

Anadolu imam hatip liseleri müfredatında zorunlu ve seçmeli olarak bütün sınıflarında Arapçaya yer verilmektedir. Bu derslerde öğrencilerin modern Arapçayı öğrenmelerinin yanında okutulan mesleki

\footnotetext{
Adres $\mid$ Address

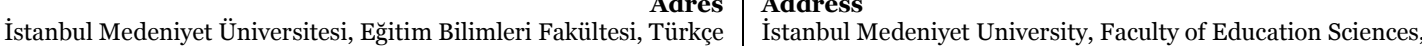
ve Sosyal Bilimler Eğitimi Bölümü, Türkçe Eğitimi ABD Cevizli $\quad$ Turkish and Social Scinces Education, Turkish Language Teaching Kampüsü, Kartal-İstanbul/TÜRKIYE $\quad$ Education, Cevizli Campus, Kartal-İstanbul /TURKEY e-posta: editor@rumelide.com 1 e-mail: editor@rumelide.com
} 
Arapça dersi sayesinde dinin temel kaynakları -Kuran ve Hadis başta olmak üzere- ile temel İslami bilimlere ait kaynakları okuyup anlamaları da hedeflenmektedir.

Anadolu İmam Hatip Lisesi Arapça Dersinin Öğretim Programının ve Mesleki Arapça Dersi Öğretim Programı”nın genel özellikleri ise şu şekildedir (Milli Eğitim Bakanlığı Din Öğretimi Genel Müdürlüğü, 2018).

Anadolu İmam Hatip Lisesi Arapça Dersinin (9-10. Sınıf) Öğretim Programı”nın vizyonu, Arapça öğrenmeye ilgi duyan, Arapça bilgi düzeyini sürekli geliştirmeye istekli, başkalarıyla işbirliği yaparak birlikte öğrenen ve özgüvenle günlük yaşantısında Arapçayı konuşabilen, bunun yanı sıra İslâmi kaynaklardan da istifade edebilen bireyler yetiştirmek üzerine kuruludur. Program iletişimsel yaklaşımın yanı sıra öğrenilenlerin tekrar edilmesine ve aşamalı olarak yeni bilgilerin öğrenilenlere ilave edilmesine dayanan "sarmal yaklaşımı" da temel almaktadır. İletişimsel ve sarmal yaklaşımlara ek olarak programda; yakından uzağa, basitten karmaşığa, somuttan soyuta olmak üzere öğrenci merkeze alınarak dinleme-anlama, konuşma, okuma ve yazma becerilerine yoğunlaşılmıştır. "Anadolu İmam Hatip Lisesi Arapça Dersi Öğretim Programı”her sınıf düzeyi için 6 tema ve her bir tema için de 3 konudan oluşmaktadır. Ayrıca programda dört temel dil becerisine yönelik kazanımlar ve bu kazanımlarla ilgili açıklamalar yer almaktadır.

Genel amaçları (Arapça, 9-10. Sinıf) ise,

Anadolu İmam Hatip Lisesi Arapça Dersi Öğretim Programı, Türk millî eğitiminin genel amaçları ve temel ilkelerine uygun olarak ögrrencilerin;

- Arapça öğrenmeye istekli olmalarını, olmalarını,

- Türk kültür ve geleneklerini fark ederek, Arap coğrafyası ve kültürü hakkında bilgi sahibi

- Arap dilinde dinleme-anlama, konuşma, okuma ve yazma dil becerilerini geliştirmelerini, etmelerini,

-Seviyelerine uygun hareketli veya hareketsiz görselleri, işitsel ve yazılı kaynakları takip

-Bilgi teknolojilerinden yararlanarak öğrenme becerilerini geliştirmelerini hedeflemektedir.

“Mesleki Arapça Dersi (11-12. Sınıflar) Öğretim Programı”nın vizyonu; "Dört Temel Dil Beceri”sinin yanı sıra "Temel Dinî Kaynakları Tanıma ve Kullanma", "Dinî Metinleri Anlama ve Yorumlama" gibi becerileri gelişmiş, İslami ilimlere ait klasik/güncel Arapça literatür ve metinlerden yararlanabilen bireyler yetiştirmektir.

"Mesleki Arapça Dersi Öğretim Programında" da tema ve kazanımlar oluşturulurken "sarmal yapı" dikkate alınmıştır. Öğretim programında, imam hatip lisesi meslek derslerinde okutulan bazı derslere ait içerikler dikkate alınarak temalar oluşturulmuş, temanın içeriğine yönelik etkinlik, kavram ve becerilere yer verilmiştir.

Genel Amaçları ise,

“Mesleki Arapça Dersi Öğretim Programı”, 1739 Sayılı Millı̂ Eğitim Temel Kanunu’nda yer alan “Türk Millî Eğitiminin Genel Amaçları ve Temel İlkeleri”ne uygun olarak öğrencilerin;

(1)İslami ilimlere ait klasik/güncel Arapça literatür ve metinlerden yararlanabilmelerini, 
The importance of individual works and cooperation of higher education and secondary education institutions in improving the quality of Arabic language teaching /M. Öztürk (pp. 898-914)

(2) İmam hatip lisesi meslek derslerinde edindikleri kazanımları pekiştirmelerini,

(3)Arapça dinleme-anlama, konuşma, okuma-anlama ve yazma becerilerini geliştirmelerini,

(4) Bazı dil bilgisi kurallarını öğrenmelerini,

(5) Seviyelerine uygun görsel, işitsel ve yazılı kaynakları takip etmelerini,

(6) Arapça öğrenmeye yönelik ilgi ve isteklerini sürdürmeyi hedeflemektedir.

Program değerlendirildiğinde,

a. Programın vizyonunda Arapça öğrenmeye ilgi duyan, Arapça bilgi düzeyini sürekli geliştirmeye istekli, başkalarıyla işbirliği yaparak birlikte öğrenen ve özgüvenle günlük yaşantısında Arapçayı konuşabilen, bunun yanı sıra İslâmi kaynaklardan da istifade edebilen bireyler yetiştirmek olarak belirleyerek uygulanacak programın genel amacının net bir şekilde ifade edildiği görülmektedir.

b. Program dil öğretiminde etkin bir yaklaşım olan iletişimsel yaklaşımın yanında sarmal yaklaşımı benimsemesi programın öğrenilen bilgilerin sürekli olarak ileriki aşamalarda hatırlanmasını sağlamayı hedeflediğini göstermektedir.

c. Program bu yaklaşımlara ek olarak; yakından uzağa, basitten karmaşığa, somuttan soyuta olmak üzere öğrenci merkeze alınarak dinleme-anlama, konuşma, okuma ve yazma becerilerine yoğunlaşma amacında olması programın Arapça öğretiminde dil öğretimindeki genel metot ve teknikler ile stratejileri öncelediğini göstermektedir.

d. Programın hedefleri arasında öğrencilerin motive edilmesi, öğrenci merkezli bir yapıyı benimsemesi ve dil öğretimde dört temel beceriyi esas alması programın dil öğretimi stratejisi açısından bilimsel bir yaklaşımla ele alındığının bir göstergesi görülmektedir.

e. Dil öğretiminde yıllarca ihmal edilen konulardan biri olan öğrenilen dilin coğrafyası ve kültürü hakkında bilgilerin verilmesinin gerekliliği bu programda hedefler arasında yer alması program açısından çok önemlidir.

f. Program öğrencilerin bilgi teknolojilerinden yararlanarak öğrenme becerilerini geliştirmelerini hedeflerinin arasına koyması programın sadece öğretici ile yapılan yüz yüze eğitim ile yetinmediğini ders dışı etkinliklerle bireysel öğrenmeyi teşvik ederek öğrencilerin kendilerini geliştirmelerine fırsat verecek bir mantıkla kurgulanmış olduğunu göstermektedir. Bu durumda programın başarısını artıran bir etken olarak görülmektedir.

g. Program öğrencilerin seviyelerine uygun hareketli veya hareketsiz görselleri, işitsel ve yazılı kaynakları takip etmelerini hedeflerinin arasına koyması da programın başarıya ulaşmasında çok önemlidir. Çünkü dilin dört temel becerisinin geliştirilmesinde farklı görsel ve işitsel materyallerin kullanılması gereklidir. Bugün yabancı dil öğretiminde yaygın olarak medya araçlarının kullanıldığı bir gerçektir. Bunun içinde Arapça öğretiminde ihmal edilen bu duruma programda yer verilmesi programın güçlü bir tarafı olarak görülmektedir. Çünkü başta Arapça yayın yapan televizyon, radyo ve internet portallarını ve çeşitli yazılı materyalleri takip etmeleri sayesinde öğrenciler dil becerilerini artıracak ayrıca kullanılan güncel Arapça dil yapılarını da kolayca elde edebileceklerdir.

\footnotetext{
Adres $\mid$ Address

İstanbul Medeniyet Üniversitesi, Eğitim Bilimleri Fakültesi, Türkçe İstanbul Medeniyet University, Faculty of Education Sciences, ve Sosyal Bilimler Eğitimi Bölümü, Türkce Eğitimi ABD Cevizli Turkish and Social Scinces Education, Turkish Language Teaching Kampüsü, Kartal-İstanbul/TÜRKIYE $\quad$ Education, Cevizli Campus, Kartal-İstanbul /TURKEY e-posta: editor@rumelide.com 1 e-mail: editor@rumelide.com
} 


\subsubsection{Yükseköğretim kurumlarında Arapça öğretimi ve Arapça öğretimi programının genel özellikleri}

Yükseköğretim kurumlarımızda Arapça öğretimi İlahiyat ve İslami İlimler Fakülteleri’nin Arap Dili ve Belagati Anabilim dalı, Yabancı Diller Yüksekokulları, Edebiyat Fakültelerinin Arap Dili ve Edebiyatı Bölümü, Eğitim Fakültelerinin Arap Dili Eğitimi Bölümü ve -üniversitelere göre farklllık göstermekle birlikte- Yabancı Diller Yüksekokulları veya Edebiyat Fakültelerine bağlı Mütercim-Tercümanlık bölümlerinde yapılmaktadır. Bu kurumlardan İlahiyat ve İslami İlimler Fakülteleri’nin çoğunda zorunlu hazırlık sınıflarına yer verilmiş, Mütercim-Tercümanlık bölümlerinde ise zorunlu hazırlık sınıfları mecburi tutulurken diğer bölümlerde ise üniversitelerin tercihine bırakılmıştır.

Yükseköğretim kurumlarında Arapça öğretimi diğer dillerin öğretimi gibi "Yükseköğretim Kurumlarında Yabancı Dil Öğretimi ve Yabancı Dille Öğretim Yapılmasında Uyulacak Esaslara ilişkin Yönetmelik" hükümlerine göre yapılmaktadır. Yükseköğretimde kurumlar Arapça öğretiminde bu yönetmeliği esas alarak kendi şartlarına da uygun bir Arapça öğretimi vermek için çeşitli yönergeler çıkarmaktadırlar. Çıkarılan bütün yönergeler Arapça öğretiminde amacı belirlerken Yönetmelik’in 5 . Maddesinde ifade edilen dil öğretiminin ve yabancı dilde öğretimin amacı temel alınmıştır. Yönetmelik'in 5. Maddesi amacı şu şekilde belirlemiştir (Resmi Gazete, 2016).

Yabancı dil öğretiminin amacı, öğrenciye aldığı yabancı dilin temel kurallarını öğretmeyi, yabancı dil kelime haznelerini geliştirmeyi, yabancı dilde okuduğunu ve duyduğunu anlayabilmeyi ve kendisini sözlü veya yazılı olarak ifade edebilmeyi; yabancı dilde öğretimin amacı ise önlisans, lisans ve lisansüstü diploma programı mezunlarının alanlarına ilişkin yabancı dil yeterliliklerini kazanmalarını sağlamaktır.

Yükseköğretim kurumlarımızdan Necmettin Erbakan Üniversitesi Ahmet Keleşoğlu İlahiyat Fakültesi Yönergesi’nin 5. Maddesinde Hazırlık Sınıfı Arapça eğitim-öğretiminin amacını,

öğrencilere kayıt oldukları İlahiyat Fakültesi eğitim-öğretim programlarının öngördüğü dersleri izleyebilmek için Arapça okuma, anlama, yazma, konuşma ile ilgili temel bilgi ve becerileri kazandırmak, çeşitli alanlardaki yayınları izleyebilme becerisini edindirmek ve sosyal hayatta gereken dil iletişimini sağlama yeterliği kazandırmaktır şeklinde belirtmiştir (Necmettin Erbakan Üniversitesi Ahmet Keleşoğlu İlahiyat Fakültesi Zorunlu Arapça Hazırlık Sınıfı Eğitim- Öğretim ve Sinav Yönergesi, 2019).

Nevşehir Hacı Bektaş Üniversitesi İlahiyat Fakültesi Yönergesi’nde ise amacını,

Arapça hazırlık sınıfının amacı; öğrencilere alanı ile ilgili olarak Arapça kaynaklardan okuduğunu ve duyduğunu anlayabilme, duygularını ve düşüncelerini yazılı ve sözlü olarak ifade edebilme, Arapça dil becerisini gerçekleștirebilme yeterliliği kazandırmaktır (Nevşehir Hacı Bektaş Veli Üniversitesi İlahiyat Fakültesi Zorunlu Arapça Hazırlık Sınıfı Uygulama Yönergesi).şeklinde ifade etmiştir.

İslami İlimler Fakültelerinden Karamanoğlu Mehmet Bey İslami İlimler Fakültesi ise uygulamış olduğu hazırlık sınıflarındaki Arapça eğitiminin amacını şu şekilde ifade etmiştir (Karamanoğlu Mehmetbey Üniversitesi İslami İlimler Fakültesi Zorunlu Arapça Hazırlık Sınıfı Eğitim- Öğretim ve Sinav Yönergesi, 2016).

Hazırlık eğitim-öğretiminin amacı, öğrencilere kayıt oldukları eğitim-öğretim programlarının öngördüğü yabancı dilde kendi alanlarında okuduğunu ve duyduğunu anlayabilme, bu dilde ve Türkçe metinleri karşılıklı çevirebilme, yazılı ve sözlü olarak kendilerini yeterince anlatabilme, kültürel ve sosyal hayatta gerekli olan dil iletişimini sağlayabilme, bilimsel ve teknolojik gelişmeleri yabancı dilde izleyebilme becerisini kazandırmaktır.

Adres

İstanbul Medeniyet Üniversitesi, Eğitim Bilimleri Fakültesi, Türkçe ve Sosyal Bilimler Eğitimi Bölümü, Türkçe Eğitimi ABD Cevizli Kampüsü, Kartal-İstanbul/TÜRKIYY e-posta: editor@rumelide.com 
The importance of individual works and cooperation of higher education and secondary education institutions in improving the quality of Arabic language teaching /M. Öztürk (pp. 898-914)

Mardin Artuklu Üniversitesi Yabancı Diller Yüksekokulu Arapça Hazırlık Sınıfı Programı EğitimÖğretim ve Sınav Yönergesi’nde hazırlık sınıfının amacı şu şekilde belirlenmiştir (Artuklu Üniversitesi Arapça Hazırlık Sınıfı Programı Eğitim- Öğretim ve Sınav Yönergesi).

Arapça hazırlık sınıfı eğitim-öğretiminin amacı, öğrencilere 23.03.2016 tarih ve 29662 sayılı Resmî Gazete'de yayımlanan Yükseköğretim Kurumlarında Yabancı Dil Öğretimi ve Yabancı Dille Öğretim Yapılmasında Uyulacak Esaslara İlişkin Yönetmelik ve 24.08.2019 tarih ve 30868 sayılı Resmî Gazete'de yayımlanan Mardin Artuklu Üniversitesi Yabancı Diller Yüksekokulu Hazırlık Sinıfı Programı Eğitim, Öğretim ve Sinav Yönetmeliği hükümleri çerçevesinde kayıt oldukları ilgili fakülte, yüksekokul ve/veya bölümlerde eğitim-öğretim programlarının öngördüğü dersleri takip edebilmek için Arapça okuma, anlama, yazma ve konuşma ile ilgili temel bilgi ve beceriler yanında meslekî ve sosyal hayatta gerekli olan Arapça dil yeterliliğini kazandırmaktır.

Ankara Yıldırım Beyazıt Üniversitesi İnsan ve Toplum Bilimleri Fakültesi Mütercim-Tercümanlık (Arapça) Programı Zorunlu Arapça Hazırlık Sınıfı Programı Eğitim-Öğretim ve Sınav Yönergesi’nde hazırlık sınıfının amacı şu şekilde belirlenmiştir (Ankara Yıldırım Beyazıt Üniversitesi Arapça Hazırlık Sınıfı Eğitim- Öğretim ve Sınav Yönergesi).

Hazırlık Sınıfı eğitim-öğretiminin amacı; öğrencilere Arapçanın temel kurallarını öğretmek, sözlü ve yazılı anlatma, okuma-anlama ve dinleme-anlama ile ilgili bilgi ve becerileri kazandırmak, kayıt oldukları İnsan ve Toplum Bilimleri Fakültesi, Mütercim Tercümanlık (Arapça) Programının öngördüğü dersleri takip edebilmek, akademik ve sosyal yaşamda gerekli olan dil iletişimini sağlayacak beceriyi kazandırmak ve çeşitli alanlardaki Arapça yayınları izleyebilme yeterliğine sahip olmalarını sağlamaktır.

Arapça hazırlık sınıflarına yer veren farklı kurum ve türdeki yükseköğretim kurumlarının yönergelerindeki amaçlarının "Yükseköğretim Kurumlarında Yabancı Dil Öğretimi ve Yabancı Dille Öğretim Yapılmasında Uyulacak Esaslara İlişkin Yönetmelik” hükümlerine göre belirlendiği ve belirledikleri amaçlarının çok benzer olduğu görülmektedir. Bu kurumlar Yüksek Öğretim Kurumunun çerçeve programına uygun, kurumlarının hedefleri ile uyumlu dersler ve bu derslerin kazanımlarını belirleyerek Arapça eğitimi vermektedirler.

Arapça hazırlık uygulayan Yükseköğretim Kurumları bu sınıflarında;

- Öğrenciye aldığı yabancı dilin temel kurallarını öğretmeyi, yabancı dil kelime haznelerini geliştirmeyi,

- Yabancı dilde okuduğunu ve duyduğunu anlayabilmeyi ve kendisini sözlü veya yazılı olarak ifade edebilmeyi;

- Ön lisans, lisans ve lisansüstü diploma programı mezunlarının alanlarına ilişkin yabancı dil yeterliliklerini kazanmalarını sağlamayı,

- Öğrencilere kayıt oldukları İlahiyat Fakültesi eğitim-öğretim programlarının öngördüğü dersleri izleyebilmek için Arapça okuma, anlama, yazma, konuşma ile ilgili temel bilgi ve becerileri kazandırmak,

- Çeşitli alanlardaki yayınları izleyebilme becerisini edindirmeyi,

- Sosyal hayatta gereken dil iletişimini sağlama yeterliği kazandırmayı,

- Öğrencilere alanı ile ilgili olarak Arapça kaynaklardan okuduğunu ve duyduğunu anlayabilme, duygularını ve düşüncelerini yazılı ve sözlü olarak ifade edebilmeyi,

- Öğrencilere kayıt oldukları eğitim-öğretim programlarının öngördüğü yabancı dilde kendi alanlarında okuduğunu ve duyduğunu anlayabilmeyi,

- Arapça ve Türkçe metinleri karşılıklı çevirebilmeyi,

- Bilimsel ve teknolojik gelişmeleri yabancı dilde izleyebilme becerisini kazandırmayı amaçlamıştır. 
Arapça dil öğretimi yapan Yükseköğretim kurumlarının ortak amacı ise öğrencinin öğrenim gördüğü programlarda yer alan dersleri okuyabilmeleri için kendilerine gerekli dört temel becerinin kazanmasını sağlayan temel bilgi ve beceriler ile meslekî, ilmî ve günlük hayatında gerekli olan dil yeterliliğini kazanmasıdır.

Kurumlarda verilen Arapça eğitiminde program öğrencinin dilin dört temel becerisini kazanması ve öğrenim gördüğü kurumun amaçlarına uygun dil ile ilgili becerileri edinmesini sağlayacak bir şekilde düzenlenmiştir.

Hazırlık sınıflarına yer vermeyen İlahiyat ve İslami İlimler fakülteleri bu sınıftaki Arapça derslerini diğer sınıflara dağıtarak Arapça öğretimindeki hedeflerine ulaşmak isterken, Arapça öğretiminin yapıldığı mütercim tercümanlık bölümlerinde hazırlık sınıflarına ek olarak bütün sınıflarında yer verdiği farklı dersler ile, Arap Dili ve Edebiyatı bölümleri ise hazırlık harici bir program uygulayarak Arapça öğretimindeki hedeflerine uygun Arapça eğitimi yapmaktadırlar.

Arap Dili Öğretmenliği bölümleri ise üniversitenin tercihine bağlı olarak hazırlık sinıflarına yer verirken lisans düzeyinde Yükseköğretim Kurulunun kararı doğrultusunda alan derslerine yer vermektedir. Kurul aldığı karar neticesinde dersleri Alan Eğitimi Dersleri (AE) \%45-50; Öğretmenlik Meslek Bilgisi Dersleri (MB) \%30-35ve Genel Kültür Dersleri (GK) \%15-20 olmak üzere yine üç grupta toplamıştır. Buna göre bu bölümlerde Arapça eğitimi ile ilgili dersler toplam derslerin \%45-50 si kadar olmak zorundadır.

Yükseköğretim Kurulu (YÖK) Arapça Öğretmenliği Bölümünün ders bazında hedef-kazanımlarını içeren eğitim programını kendisi oluşturarak fakültelerden bu programı uygulamalarını istemiştir. Yükseköğretim Kurulu 18 Ağustos 2020 tarihinde aldığı bir karar neticesinde eğitim fakültelerine kendi müfredatlarını oluşturma olanağı da sağlamıştır.

Arapça eğitimi verilen kurumların farklı amaçları olması nedeniyle müfredatlarının farklılaşması bir zorunluluktur. Bununla birlikte bu fakülte ve bölümlerde temel Arapçanın kazandırılmasında benzer derslerinde bulunacağı bir gerçektir. Farklı fakülte ve bölümlerde farklı isimlerle ifade edilse de;

çeşitli sözlü iletişim durumları için uygun ifadeler ve stratejiler kullanarak sözlü iletişim kurma becerisinin geliştirilmesi; karşıllklı konuşma, sunum, tartışma etkinlikleri yoluyla duygu ve düşünceleri etkin ifade edebilme becerisinin geliştirilmesi; güncel, özgün, işitsel, görsel-işitsel malzemeler kullanılarak konuşma ve duyduğunu anlama becerisinin geliştirilmesini sağlayan Sözlü İletişim Becerileri, gazete, dergi, inceleme ve akademik yazılar gibi özgün okuma parçaları kullanılarak farklı bakış açılarını kavrama; tümceler arası bağlantıları ve yazının ana fikrini tahmin etme, ana fikre ulaşma ve cümleler arası anlamsal ipuçlarını kullanabilme gibi üst düzey okuma becerilerinin kazandırılması; ders içi ve ders dışı okuma alışkanlığının kazandırılması; bilginin sentezlenmesi, analizi ve değerlendirilmesi temeline dayanan eleştirel düşünme becerilerinin geliştirilmesini sağlayan Okuma Becerileri, Paragraf biçimleri ve yapısı; paragrafın teknik özellikleri; paragraf çözümleme; paragraf planı çıkarma; betimleme, karşılaştırma, tartışma, anlatma türleriyle metin üretme, özet yazma, yorumlama; kısa hikâye, inceleme yazısı (kitap ve/veya film üzerine) ve resmî/gayrı resmî mektup yazmayı sağlayan Yazma Becerileri, Orta ve ileri düzeydeki dil yapılarını, sözcükler arasındaki ilişkiyi ve sözcük türetme kurallarını kavrama ve bu dil yapıları aracılığıyla anlamlı cümleler kurma konusunda bilinçlenme; söz konusu dil yapılarını modern standart Arapça ile örneklendirerek ve diğer dil becerileriyle entegre hâle getirerek bağlam içinde verme ve öğrencinin bu bilgiden kaynaklanan orta ve ileri seviyede metin üretmesini sağlayan Arapçanın Yapısı, Farklı temalardaki haber metinlerinden başlayarak öğrencileri çeviriyle tanıştırma; kaynak metinde yer alan eşdizimsel yapılara dikkat çekerek dil becerilerini geliştirme; bir kaynak metninin farklı çevirilerinin ne derece mümkün olduğunu tartışma; çeviri uygulamalarından yola çıkarak öğrencilerde çeviri farkındalığı oluşturmayı sağlayan ArapçaTürkçe Çeviri, Başta haber çevirisi olmak üzere temel düzeyde kontrollü çeviri uygulamaları, bu uygulamalar üzerinden öğrencilere kuramsal çıkarımlar yaptırma, öğrencilerin kendi çeviri

Adres

İstanbul Medeniyet Üniversitesi, Eğitim Bilimleri Fakültesi, Türkçe ve Sosyal Bilimler Eğitimi Bölümü, Türkçe Eğitimi ABD Cevizli Kampüsü, Kartal-İstanbul/TÜRKIYE e-posta: editor@rumelide.com
Address

İstanbul Medeniyet University, Faculty of Education Sciences,

Turkish and Social Scinces Education, Turkish Language Teaching

Education, Cevizli Campus, Kartal-İstanbul /TURKEY

e-mail: editor@rumelide.com 
The importance of individual works and cooperation of higher education and secondary education institutions in improving the quality of Arabic language teaching /M. Öztürk (pp. 898-914)

ürünlerini değerlendirmelerini sağlama; cümle düzeyinden metin düzeyine doğru öğrencilerin sözcük dağarcı̆̆ını da artırarak çeşitli temalarda haber düzeyinde çeviriler yaptırma ve yapılan çevirileri birlikte değerlendirme, bu değerlendirmeler üzerinden temel düzeyde çeviri bilim kavramlarını tartışmayı sağlayan Türkçe-Arapça Çeviri (Yükseköğretim Kurulu Arapça Öğretmenliği Lisans Programı).

gibi temel Arapça derslerine yer verildiği görülmektedir.

\subsubsection{Anadolu İmam Hatip Lisesi Arapça dersinin öğretim programı ile Yükseköğretim kurumlarında Arapça eğitiminin programının karşılaştırılması}

Ülkemizde eğitim sistemi bilindiği gibi temel öğretim, ortaöğretim, yükseköğretim şeklinde düzenlenmiştir. Okul öncesi eğitim ile formal eğitime başlayan birey neredeyse hayatının üçte birini yükseköğretim sonrası nitelikli bir meslek sahibi olmak için harcamaktadır. Eğitim çok yönlü bir kavramdır. Psikolojik, toplumsal ve ekonomik bir yönü de olan eğitim toplumun huzurlu ve rahat bir şekilde yaşamanın ve ülke kalkınmasının da ilk şartıdır. Bundan dolayı bütün toplumlar eğitime büyük önem vermişlerdir.

Günümüzde her şeyin hızlı bir değişim içerisinde olduğu teknoloji çağında artık içerisinde bulunduğumuz çağa göre değil, gelecek çağlara göre bir eğitim yapılması kaçınılmaz görülmektedir. $\mathrm{Bu}$ internet çağında dünyanın bir köy haline geldiği günümüzde iletişimin önemi bilinmektedir. Eğitim sistemimizde bu gerçek çok öncelerden bilinmesine rağmen yllarca verilen emek ve çabaya oranla başta İngilizce olmak üzere yabancı dil eğitiminde istenilen başarıya ulaşılamadığı da yadsınamaz bir gerçektir. Bu durum Arapça öğretimi içinde geçerlidir. İmam hatip ortaokulları, liseleri ve ardından İlahiyat ve İslami İlimler Fakülteleri ile Arapça eğitimi veren yükseköğretim kurumlarında öğrenim gören çoğu öğrenci neredeyse çocukluk yaşında başladığı Arapçayı istenilen bir seviyede öğrenememektedir. Bunun dil öğretiminde konulan hedef-davranışlardan, müfredattan kullanılan teknik-metot ve materyale kadar birçok nedeni üzerinde durulmuştur. Çalışmanın bu kısmında ise programların çeşitli yönlerden karşılaştırılmasına çalışılacaktır.

\subsubsection{Programların dayandıkları yönetmelikler açısından karşılaştırılması}

Ülkemizde ortaöğretim kurumlarında Arapça öğretimi, Milli Eğitim Bakanlığı Yabancı Dil Eğitimi ve Öğretimi Yönetmeliği, Yükseköğretim Kurumlarında ise Yabancı Dil Öğretimi ve Yabancı Dille Öğretim Yapılmasında Uyulacak Esaslara ilişkin Yönetmelik hükümlerine göre yapılmaktadır.

Örgün, yaygın ve uzaktan öğretim kurumlarındaki yabancı dil eğitimi ve öğretiminin amacı, Millî Eğitimin genel amaç ve temel ilkelerine uygun olarak okul ve kurumların amaç ve seviyeleri de göz önünde bulundurularak eğitim ve öğretimi yapılan yabancı dilde bireylerin; "Dinleme-anlama, Okuma-anlama,Konuşma, Yazma becerileri kazanmalarını, öğrendiği dille iletişim kurmalarını ve yabancı dil öğretimine karşı olumlu tutum geliştirmelerini sağlamak" şeklinde belirlenirken, "Yabancı Dil Öğretimi ve Yabancı Dille Öğretim Yapılmasında Uyulacak Esaslara İlişkin Yönetmelik" hükümlerine göre yükseköğretim kurumlarında ise dil eğitiminin amacı, öğrenciye aldığı yabancı dilin temel kurallarını öğretmeyi, yabancı dil kelime haznelerini geliştirmeyi, yabancı dilde okuduğunu ve duyduğunu anlayabilmeyi ve kendisini sözlü veya yazılı olarak ifade edebilmeyi; yabancı dilde öğretimin amacı ise önlisans, lisans ve lisansüstü diploma programı mezunlarının alanlarına ilişkin yabancı dil yeterliliklerini kazanmalarını sağlamaktır" olarak belirlenmiştir.

Adres

İstanbul Medeniyet Üniversitesi, Eğitim Bilimleri Fakültesi, Türkçe ve Sosyal Bilimler Eğitimi Bölümü, Türkce Eğitimi ABD Cevizli Kampüsü, Kartal-İstanbul/TÜRKIYE e-posta: editor@rumelide.com 
Yabancı dilde uygulanan programlar karşılaştırıldığında ortaöğretimde yabancı dil öğretimine karşı olumlu tutum geliştirmelerini sağlamak ve yükseköğretimde ise önlisans, lisans ve lisansüstü diploma programı mezunlarının alanlarına ilişkin yabancı dil yeterliliklerini kazanmalarını sağlamak gibi eğitim süreçlerine göre farklı amaçları da olsa her iki programında amacının benzer olduğu görülmektedir. İletişim becerisini ve dilde dört temel beceriyi kazandırmak bu kurumlarımızın ortak amacıdır.

\subsubsection{Programların amaçları açısından karşılaştırılması}

İmam hatip liselerinin Arapça öğretim programlarının genel amaçları öğrencilerin Arapça öğrenmeye istekli olmalarını, Türk kültür ve geleneklerini fark ederek Arap coğrafyası ve kültürü hakkında bilgi sahibi olmalarını, Arap dilinde dinleme-anlama, konuşma, okuma ve yazma dil becerilerini geliştirmelerini, seviyelerine uygun hareketli veya hareketsiz görselleri, işitsel ve yazılı kaynakları takip etmelerini, bilgi teknolojilerinden yararlanarak öğrenme becerilerini geliştirmelerini, İslami ilimlere ait klasik/güncel Arapça literatür ve metinlerden yararlanabilmelerini, imam hatip lisesi meslek derslerinde edindikleri kazanımları pekiştirmelerini, Arapça dinleme-anlama, konuşma, okumaanlama ve yazma becerilerini geliştirmelerini, bazı dil bilgisi kurallarını öğrenmelerini, seviyelerine uygun görsel, işitsel ve yazılı kaynakları takip etmelerini, Arapça öğrenmeye yönelik ilgi ve isteklerini sürdürmeyi hedeflemektedir.

Kurumların ortak amaçları ise öğrencinin öğrenim gördüğü programlarda yer alan dersleri okuyabilmeleri için kendilerine gerekli Arapça okuma, anlama, yazma ve konuşma ile ilgili temel bilgi ve becerileri kazanmasının yanında meslekî, ilmî ve günlük hayatında gerekli olan Arapça dil yeterliliğini kazanmasıdır.

Her iki programında:

- Öğrencilere Arapça okuma, anlama, yazma ve konuşma ile ilgili temel bilgi ve becerileri ve meslekî ve sosyal hayatta gerekli olan Arapça dil yeterliliğini kazandırmak (İmam Hatip Liseleri ve Arapça öğretim yapan bütün yükseköğretim kurumlarının amacı)

- Öğrenim gördüğü Temel İslami Bilimlere ait metinleri klasik/güncel Arapça literatür ve metinlerden yararlanabilmek (İmam Hatip Liseleri, İlahiyat ve İslami İlimler Fakültelerinin amacı) olarak belirlemiştir.

\subsubsection{Programların dayandığı yaklaşımlar açısından karşılaştırılması}

“Anadolu İmam Hatip Lisesi Arapça Öğretim Programı”nın vizyonu, Arapça öğrenmeye ilgi duyan, Arapça bilgi düzeyini sürekli geliştirmeye istekli, başkalarıyla işbirliği yaparak birlikte öğrenen ve özgüvenle günlük yaşantısında Arapçayı konuşabilen, bunun yanı sıra İslâmi kaynaklardan da istifade edebilen bireyler yetiştirmek olan program iletişimsel yaklaşımın yanı sıra öğrenilenlerin tekrar edilmesine ve aşamalı olarak yeni bilgilerin öğrenilenlere ilave edilmesine dayanan "sarmal yaklaşımı" da temel almaktadır. İletişimsel ve sarmal yaklaşımlara ek olarak programda; yakından uzağa, basitten karmaşı̆̆a, somuttan soyuta olmak üzere öğrenci merkeze alınarak dinleme-anlama, konuşma, okuma ve yazma becerilerine yoğunlaşılmıştır.

Yükseköğretim Kurumlarında ise Arapça Öğretimi² derslerin amaçları incelendiğinde Arapça öğrenmenin anlamı, Öğretim programlarıyla ilgili temel kavramlar; Arapça dersi öğretim

Anadolu İmam Hatip Lisesi Arapça Öğretim Programı ile yükseköğretim kurumları programlarının yaklaşım açısından değerlendirilmesinde Yükseköğretim kurumlarının program yaklaşımlarının ortaya konulmasında Yükseköğretim 
The importance of individual works and cooperation of higher education and secondary education institutions in improving the quality of Arabic language teaching /M. Öztürk (pp. 898-914)

programlarının geçmişten günümüze gelişimi; güncel Arapça dersi öğretim programının yaklaşımı, içeriği, geliştirmeyi amaçladığı beceriler; öğrenme ve alt öğrenme alanları, sözlü iletişim kurma becerisinin geliştirilmesi, bilginin sentezlenmesi, analizi ve değerlendirilmesi temeline dayanan eleştirel düşünme becerilerinin geliştirilmesi, betimleme, karşılaştırma, tartışma, anlatma türleriyle metin üretme, özet yazma, yorumlama; dil yapıları aracılığıla anlamlı cümleler kurma konusunda bilinçlenme gibi genel hedeflerin belirlendiği görülmektedir. Müfredatta belirlenen hedefler ışığında programda yer alan derslerin öğrenci merkezli bir yapıda, kolaydan zora aşamalı bir şekilde, ezberci anlayıştan uzak öğrencilerin öğrendiği bilgileri analiz ve sentez etmelerini isteyen, iletişimci yaklaşımın ön plana çıktığı, eleştirel düşünmeye ve çağdaş yaklaşımlarla öğrendiği dili yine bu yaklaşımlarla öğretimini yapmasını istediği bir mantıkla kurgulanmıştır.

Programların her ikisinin de çağdaş Arapça öğrenimini benimseyen, geleneksel anlayışın aksine öğrenci merkezli bir öğretimi önceleyen, dört temel becerinin öğretilmesini amaçlayan, dil öğretiminde iletişimsel yaklaşımı kabul eden, ezberci anlayıştan uzak niçin öğrendiğinin farkına varan, öğrendiklerini analiz, sentez ederek değerlendirebilen, yani öğrenmeyi öğrenen bireylerin yetiştirilmesi anlayışı üzerine kurulduğunu görmekteyiz. Böyle bir Arapça öğretiminin benimsendiği bir yaklaşımın dil öğretiminde son yıllarda kabul gören anlayış ile uyumlu olduğu görüşündeyiz.

\subsubsection{Anadolu İmam Hatip Liseleri dışındaki ortaöğretim kurumlarındaki Arapça öğretiminin durumu}

Ortaöğretim kurumlarımızda okutulacak dersler ve ders saatleri Milli Eğitim Bakanlığı Talim Terbiye Kurulu tarafından belirlenmektedir. Kurul tarafından yayımlanan karara göre ortaöğretim kurumlarının farklı türlerine göre yabancı dil derslerine yer verilmiştir. Bu karara göre liselerde yabancı dil dersleri 1. Yabancı Dil ve 2. Yabancı Dil olarak belirtilmiştir. Yine bu kararda Bakanlık Kurulunca belirlenen Almanca, Fransızca, Arapça, Çince, Rusça, Japonca, Farsça, Korece ve Urduca dilleri kabul edilmiştir.

Kurul buna ek olarak 2. Yabancı Dil adıyla ikinci bir dilin ortaöğretim kurumlarından bazı okul türlerinde okutulmasını istemiştir. Dil öğrenilmesinin önemli amaçlarından birinin de turizm ve ticaret olduğu bilinmektedir. Zaten belirlenen dillerde de bunu görmek mümkündür. Ülkemizin bugün çeşitli nedenler ile Arap Devletleri ile başta turizm ve ticaret olmak üzere devletlerarası ilişkilerini giderek artırdığı açık bir şekilde görülmektedir. Böyle bir ortamda Arapçanın önemi ortaya çıkmaktadır. Fakat Anadolu İmam Hatip Liseleri dışındaki ortaöğretim kurumlarımızdaki dil öğretimi uygulamasına bakıldığında durumun Arapça öğretimi için iyi bir durumda olmadığı görülmektedir.

Milli Eğitim Bakanlığı Talim ve Terbiye Kurulu Başkanlığı 19/o2/2018 tarih 56 Sayılı Ortaöğretim Kurumları Haftalık Ders Çizelgesinde anadolu ve fen liselerinde 1. yabancı dil ile birlikte zorunlu olarak 2. yabancı dile yer vermiştir. Kurul güzel sanat ve spor liselerinde ise ortak dersler bölümünde 1 . yabancı dile, seçmeli derslerde ise 2. yabancı dile yer vermiştir.

Bugün liselerde öğrencilerin sadece Batı dilleri olarak adlandırdığımız başta İngilizce olmak üzere Almanca, Fransızca gibi dillere yöneldikleri veya yönelmek zorunda kaldıkları görülmektedir. Bu liselerin tamamına yakınında başta İngilizce olmak üzere bu dillerin 1. Yabancı dil olarak okutulduğu başka bir dile neredeyse yer verilmediği görülmektedir. Bugün Ayrıca liselerde 2. Yabancı dil olarak da

Kurulu tarafından Eğitim Fakülteleri Arapça Öğretmenliği bölümü için hazırlanan müfredat temel alınmıştır. Yükseköğretim kurumları tarafından hazırlanan Arapça öğretim çerçeve programları kurulun hazırlamış olduğu müfredat mantığı ile aynı yaklaşımla hazırlanmıştır.

\footnotetext{
\begin{tabular}{r|l} 
Adres & Address \\
İstanbul Medeniyet Üniversitesi, Eğitim Bilimleri Fakültesi, Türkçe & İstanbul Medeniyet University, Faculty of Education Sciences,
\end{tabular} ve Sosyal Bilimler Eğitimi Bölümü, Türkce Eğitimi ABD Cevizli $\quad$ Turkish and Social Scinces Education, Turkish Language Teaching Kampüsü, Kartal-İstanbul/TÜRKIYY $\quad$ Education, Cevizli Campus, Kartal-İstanbul /TURKEY e-posta: editor@rumelide.com 1 e-mail: editor@rumelide.com
} 
uygulamada çoğunlukla Almancanın okutulduğu da bir gerçektir. Oysa ki liselerde okutulan bu dillerin seçmeli de olsa seçiminde kurul hedeflerini açık bir şekilde belirlemiştir. Buna göre (Milli Eğitim Bakanlığı Talim ve Terbiye Kurulu Başkanlığı, 2018),

Seçmeli dersler öğrencinin ilgi ve istekleri ile hedefledikleri yükseköğretim programları doğrultusunda öğrenci, veli ve okul tarafından ortaklaşa belirlenecektir. Birinci ve ikinci yabancı dil derslerinde Bakanlar Kurulu Kararı ile öğretiminin yapılması kabul edilen yabancı diller okutulacaktır. Ortak ve seçmeli dersler grubunda yer alan birinci ve ikinci yabancı dil dersleri birbirinden farklı olmak zorundadır.

Liselerde Arapça eğitiminin gerekçelerini şu şekilde ifade edebiliriz.

- Karar özellikle seçmeli derslerin öğrencinin ilgi ve istekleri ile hedefledikleri yükseköğretim programları doğrultusunda olmasının gerektiği konusunda vurgu yapmıştır.

- Ortaöğretimden yükseköğretimin dil bölümlerine geçişte Yükseköğretim Kurumları Sınavı yapılmaktadır. Son yıllarda bu sınavların İngilizce, Fransızca ve Almanca dillerinin yanında Arapça'dan da yapılması Arapça'ya öğrencilerin ilgisini artırmıştır.

- Ortaokullardan mezun olan öğrencilerin yaklaşı \% 15’i İmam Hatip Ortaokullarından mezun olmaktadırlar. Bu öğrenciler sadece Anadolu İmam Hatip Liselerini tercih etmemekte farklı türdeki liseleri tercih etmektedirler. Bu öğrencilerin daha önce gördükleri bir dilde eğitim yapmaları dil eğitiminde her yönden öğrenene büyük bir avantaj sağlayacağı açıktır.

- Anadolu İmam Hatip Liseleri dışındaki ortaöğretim kurumlarından mezun olan öğrencilerin dil sınavı dışında farklı bir alandan İlahiyat ve islami ilimler Fakültelerini tercih edebilmektedirler. Bu öğrencilerin lise düzeyinde alacakları bir Arapça eğitiminin tercih ettikleri Arapça eğitimi ile karşılacakları yükseköğretim kurumlarındaki başarılarını artıracaktır. Böyle bir başarının da Arapça eğitim kalitesini artıracağı açıktır. Bugün Arapça eğitimi verilen yükseköğretim kurumlarımızdaki öğrencilerin yaklaşık dörtte birini bu liselerimizden gelen öğrencilerimiz oluşturmaktadır. Liselerde verilecek Arapça eğitimi yine ilk aşamada yükseköğretim kurumlarımızdaki kaliteyi artıracaktır.

Bu gerekçeler bu kurumlarda Arapça eğitiminin öğrencilerin tercihine bir alternatif olarak sunulması için mevzuatta yer alan Arapça eğitim ile ilgili Milli Eğitim Bakanlı̆̆ı tarafından yapılacak düzenlemelerin acil olarak uygulamaya konulması için yeterli bir sebep olduğu değerlendirilmektedir.

\subsubsection{Arapça eğitimi sonunda kazanılan kazanımların istenilen seviyede bulunmamasının nedenleri ve bu sorunun çözümündeki öneriler.}

Ülkemizde yabancı dil eğitiminde ulaşılmak istenen amaçlara tam anlamı ile ulaşılamadı̆̆ı görülmektedir. Genel anlamda dil öğretiminde çok büyük sıkıntılar vardır ve bu sıkıntıların aşılamadığı düşünülmektedir.

Eğitim ve öğretimin ilk ve en önemli unsuru öğrenendir. Diğer yabancı dillerde karşllaşllan olumsuz durumlar Arapça öğretiminde de geçerlidir. Her yönüyle büyük bir çabanın verildiği Arapça öğretiminde elde edilen kazanımların yapılan çalışmalara göre yeterli olmadığı görülmektedir. Arapçanın öğretiminde hedeflenen başarının yakalanmasında, öğrencilerin bu derse karşı olumlu tutum geliştirmelerinin önemi çok büyüktür (Kömürcü, 2015). Çünkü yıllarca yapılan Arapça öğretiminde öğrencilerin Arapça öğretimindeki tutumlarının göz ardı edilmesi de istenilen sonuca ulaşılamamasının nedenlerinden biridir. Son yıllarda öğrencilerin Arapçaya ve Arapçanın öğretiminde yükseköğretimde konulan derslere karşı tutumlarının tespit edildiği çalışmaların (Kömürcü, 2015; Ekinci, 2019; Özcan ve Yapıcı, 2016) artması da bunun en güzel bir kanıtıdır. Öğrenenin tutumunun

\footnotetext{
Adres $\mid$ Address

İstanbul Medeniyet Üniversitesi, Eğitim Bilimleri Fakültesi, Türkçe ve Sosyal Bilimler Eğitimi Bölümü, Türkçe Eğitimi ABD Cevizli $\quad$ Turkish and Social Scinces Education, Turkish Language Teaching Kampüsü, Kartal-İstanbul/TÜRKIYE $\quad$ Education, Cevizli Campus, Kartal-İstanbul /TURKEY e-posta: editor@rumelide.com 1 e-mail: editor@rumelide.com
} 
The importance of individual works and cooperation of higher education and secondary education institutions in improving the quality of Arabic language teaching /M. Öztürk (pp. 898-914)

bilinmeden herhangi bir konuda öğretim yapılması durumunda başarının istenilen seviyede olmaması kaçınılmazdır. Bunun içinde Arapça öğretimine başlamadan önce öğrencilerin yetkinlik beklentilerinin yükseltici, yabancı dil öğrenme kaygı düzeylerini düşürücü etkinlikler yapılmalı ve öğrencilerin yabancı dil öğrenmeye karşı olumlu tutum geliştirmeleri sağlanmalıdır (Özcan ve Yapıcı, 2016).

Arapça öğretimi esnasında öğrenmeyi etkileyen faktörler olarak üç unsur ön plana çıkmaktadır. Bunlar: öğrenci, öğretici ve yöntemdir (Coştu, 2016). Yapılan araştırmalar sonucunda öğrenme sürecinin her bir unsuru ile ilgili geliştirici çalışmalar yapılmaya devam etmektedir. Arapça öğretiminin bu süreçleri ile birçok araştırmacı tarafından program, programın uygulayıcıları, kullanılan metot ve teknik, araç ve gereçler ve bu sürecin en önemli unsuru öğrenen açısından geniş araştırmalar yapılmıştır. Fakat bu çalışmalar bu konuda büyük bir yol almalarına rağmen yine de istenilen sonuca ulaşamamıştır. Arapça öğretiminin istenilen seviyede olmadı $\breve{g} ı$ tespit edilen çalışmalar neticesinde araştırmacılar tarafından bunun çözümü için faydalı ve bilimsel bir takım öneriler ileri sürülmüştür (Soyupek, 2008; Coştu, 2016; Özcan ve Yapıcı, 2016; Kömürcü, 2015).

Önerilerin öğrenci, öğretici ve yöntemden ibaret olan öğrenmeyi etkileyen bütün unsurları kapsadığı görülmektedir. Bu da sorunun ciddiyetini de ortaya koymaktadır. Başka bir deyişle öğrenmenin bütün unsurlarında bir takım eksikliklerin olduğunu ortaya koymaktadır. Arapça öğretiminde bu tür çalışmalara rağmen öğretimdeki yetersizlik acaba giderilebilmiş midir? Ne yazık ki böyle bir sorunun cevabının olumsuz olduğunu görmekteyiz. Öyle ise bütün bu önerilerde ifade edilen çözüm önerilerine ek birtakım sorunlarında bulunduğu gerçeğidir. Bu sorunlara ek olarak ifade edebileceğimiz büyük sorunun dil öğretiminin bir süreç olduğu, bu sürecin bütün olarak değerlendirilmesi gerektiği ve bu süreçlerin hepsini kuşatan bir mantıkla Arapça programının oluşturulması, içerisinde bulunulan şartlara göre sürekli geliştirilmesine dayanan bir eğitimin yapılmasıdır. Sorunun, -Arapça eğitimi ile ilgili çalışmalarda ve yapılan çalıştaylarda ortaöğretim ve yükseköğretim ile ilgili ortak kararlar alınmasına rağmen- eğitim programı başta olmak üzere öğretimin unsurlarını ele alırken aşama farklılığının olmasının haricinde bütün unsurlarda ortaöğretim ve yükseköğretimdeki Arapça öğretiminin ayrı ayrı kurgulanması olarak görebiliriz. Dil öğretiminin sarmal bir yapıda önceki dönemi de içine alan bir süreç olduğu gerçeği unutulmaktadır. Arapça öğretimine ortaokul, lisede ve yükseköğretimin sarmal bir yapıda aşamalılık ilkesi ile birbirini bütünlemesi gerekmektedir. Ne yazık ki, eğitim sistemimizde bu yapılmadığı için ortaöğretimden Arapça eğitimi almak için yükseköğretime geçiş yapan öğrenci alışık olmadığı bir yapı ile karşılaşabilmektedir. Her ne kadar yükseköğretim kurumları yaptıkları Arapça öğretimlerinde kendilerine verilen bilimsel özerkliklerinin bir gereği olarak farklı yaklaşımlar sergilemeleri makul görülse de çoğu yükseköğretim kurumunun uyguladıkları eğitimin çıtılarını somut bir şekilde ortaya koymamaktadırlar. Farklı araştırmacılar tarafından öğrencilerin Arapça sınıflarına karşı duyuşsal tepkilerini ölçtükleri çalışmalarında Arapçaya karşı olumsuz bir bakışın oluşmasının en büyük nedenlerinden biri de budur. Çünkü öğrenen bilmediği şeye karşı korku hissetmekte ve bu da onda olumsuz bir algıya dönüşmektedir.

Yükseköğretim kurumlarından Necmettin Erbakan Üniversitesi son yaptığı çalışmalarında eğitimdeki hedeflerin ve kazanımların somut, objektif bir şekilde oluşturulması gereğini öğretim elemanlarından ders bazında çıktıları somut bir şekilde sisteme girmelerini resmi olarak istemeleri de bu uygulamanın dil öğretiminde olduğu gibi bütün eğitimde ne kadar gerekli olduğunu göstermektedir.

$\mathrm{Bu}$ önerilere ek olarak görülen bir sorunda programların hedef davranış ve kazanımlarını objektif kriterler ile ölçülememesidir. Bugün sadece Arapça öğretiminin değil bütün yabancı dillerin öğretiminde de karşılaşllan bu sorun son yıllarda yeni farkedilen öğrencilerin Arapça öğretimine olan

Adres

İstanbul Medeniyet Üniversitesi, Eğitim Bilimleri Fakültesi, Türkçe ve Sosyal Bilimler Eğitimi Bölümü, Türkçe Eğitimi ABD Cevizli Kampüsü, Kartal-İstanbul/TÜRKIYE e-posta: editor@rumelide.com
Address

Istanbul Medeniyet University, Faculty of Education Sciences,

Turkish and Social Scinces Education, Turkish Language Teaching

Education, Cevizli Campus, Kartal-İstanbul /TURKEY

e-mail: editor@rumelide.com 
duyuşsal bakışları gibi geniş kapsamlı bir şekilde ele alınmamıştır. Öyleki ortaöğretim ve yükseköğretimde Arapça öğretim programının hedefinin dört temel beceriyi kazandırmak olması ve dört temel beceriye ait edinilmesi gereken kazanımlar açıkça ifade edilmesine rağmen program, kazanımları ölçebilecek ve sonunda değerlendirme firsatı verecek bir somut, objektif bir ölçme aracını geliştirmemiştir. Oysaki program bir süreçtir ve bu sürecin bütün aşamaları ile ilgili çözüm önerileri süren araştırmacıların bu konuda yeterince bir yönlendirmede bulunamadıkları bir gerçektir.

Özellikle bilişsel, duyuşsal ve devinişsel öğrenim alanlarına bir bütün olarak hitap eden dil öğretimi programlarında ölçme değerlendirme sistemi, diğer alanlardan çok daha karmaşık bir yapı arz etmektedir. $\mathrm{Bu}$ nedenle de Arapça öğretiminde programın hedef ve kazanımlarını ölçme ve değerlendirme konusunda Arapça öğretiminde bu sorunu tespit edip bununla ilgili bir çalışma "Üniversite Düzeyinde Arapça Öğretiminde Kullanılmak Üzere Web Tabanlı Bir Ölçme-Değerlendirme Sistemi Geliştirilmesi” isimli TÜBİTAK araştırma projesi çerçevesinde Necmettin Erbakan Üniversitesi İlahiyat Fakültesinde uygulanmak üzere tasarlanmıştır. Yapılan çalışma sayesinde, ölçme değerlendirmede objektiflik düzeyini artırarak öğrenci ve öğretmen başarı oranlarının istatistiksel olarak izlenmesine olanak sağlayacağı düşünülmüştür (Tasa ve Furat, 2012). Uygulanan bu proje sayesinde öğrencilerin bütün dil yeterliliklerini ölçebilen bir model ortaya konulmaya çalışılmıştır.

\section{Sonuç ve öneriler}

Arapça öğretiminde kaliteyi artırmak için yapılan çalışmalar neticesindeki önerilerin titizlikle ele alınması ve bu önerilerden bilimsel ve faydalı olanlarının uygulamaya geçirilmesi gerekmektedir. $\mathrm{Bu}$ önerilere yenilerinin eklendiği bu çalışmada geniş bir çalışma alanına sahip Arapça eğitiminde kaliteyi artırmak için yükseköğretim kurumları ile ortaöğretim kurumlarının kendi bünyelerinde yapacakları çalışmaların yanında ortak çalışmaların da yapılması bir zorunluluk olarak görülmelidir. Bu ortak çalışmalar Arapça programının hazırlanmasından uygulanma aşamalarına kadar geniş bir alanda ele alınmalıdır. Yükseköğretim kurumlarındaki Arapça eğitiminin ortaöğretim kurumlarında verilen eğitimin bir devamıdır. Bu nedenle de Arapça öğretimin bir süreç olduğu gerçeğinden hareketle sarmal eğitim modelinin yükseköğretimde devam ettirilmesi gerekmektedir. Yükseköğretim ve ortaöğretim kurumlarındaki öğretimin birbirini bütünlemesi ve çalışmada ifade edilen yapılacak bu ortaklaşa çalışmaların her iki kurumdaki başarıyı artıracağı açıktır. Bu çalışmalarda ayrıca öğretmenler ile de akademik bir paylaşım içerisine girileceği için problemlerin çözümü daha da kolay olacaktır. Unutmayalım ki, ortaöğretim kurumlarındaki öğrenci ileriki yllarda yükseköğretim öğrencisi olacaktır, mezuniyetinin ardından öğretmen olarak tekrar ortaöğretim kurumlarında görev alacaktır. Yani sürekli bir dönüşüm devam edecektir.

\section{Bu çalışmada ulaşılan sonuçlara göre aşağıdaki önerilerde bulunulabilir:}

- Arapça öğretiminde programın amacı belirlenirken ilk adım öğrenenin istek ve amacını belirlemek olmalıdır. Yapılacak çalışma belirlenen amaçların hangisi ve ya hangilerine ulaşmak için yapılacaktır? Bu faaliyetin Arapça öğretiminin ilk adımı olduğu unutulmamalıdır. Her bir öğrenmenin bireye katkısının olması beklenir. Çünkü katkı sağlamayan bir öğrenme birey tarafından önemsenmeyecek ve bunun sonucunda da bir öğrenme meydana gelmeyeceği açıktır. Öğrenen bu öğrenmeyi gerçekleştirdiğinde kendisine olan katkısını sorgulayacak ve bu da motivasyonunu olumlu ya da olumsuz olarak etkileyecektir. Bunun için kurumların Arapça eğitimi planlamaları yaparken bu duruma önem vermeleri gerekmektedir.

- Kurumlar Arapçanın niçin öğrenildiği, bu öğrenmenin kendilerine ne gibi faydalar sağlayacağı hakkında öğrenene gerekli bilgiler verip, öğrenenin hazırbulunuşluklarını tespit etmesi gerekmektedir.

Adres

İstanbul Medeniyet Üniversitesi, Eğitim Bilimleri Fakültesi, Türkçe ve Sosyal Bilimler Eğitimi Bölümü, Türkçe Eğitimi ABD Cevizli Kampüsü, Kartal-İstanbul/TÜRKIYE e-posta: editor@rumelide.com 
The importance of individual works and cooperation of higher education and secondary education institutions in improving the quality of Arabic language teaching /M. Öztürk (pp. 898-914)

- İmam hatip liselerini tercih eden imam hatip ortaokulları başta olmak üzere diğer ortaokul seviyelerinde eğitim yapan okullarda öğrencilere Arapça öğretimi konusunda rehberlik servislerince bilgilendirme yapılmalıdır. Bu nedenle de başta rehber öğretmenler olmak üzere, idareci ve öğretmenlere bu konuda hizmet içi eğitim çalışmaları ve çeşitli bilgilendirme faaliyetleri akademisyenler tarafından yapılmalıdır. Bu bilgilendirmeler yüzyüze yapılacağı gibi, online olarak da gerçekleştirilebilir.

- Eğitim kurumlarımızda istenilen kalitede bir Arapça eğitimi yapmak için ortaöğretim ve yükseköğretim kurumlarımızın işbirliği yapması kaçınılmazdır. Son yıllarda bunun önemi fark edilmiş ve üniversitelerimiz ile milli eğitim müdürlüklerimiz arasında protokoller imzalanmıştır. Böyle bir çalışma, Arapçaya ilgisi olan öğrencilerin erken bir zamanda tespit edilip yönlendirilmelerini ve bu konuda yapılan çalışmalarla dil yeteneklerinin geliştirilmesine büyük katkılar sağlayacaktır. Yapılacak projeler sayesinde iki kurum arasında etkileşim artacak bu da eğitimde kaliteyi artıracağı gibi kurumlara sayısız faydalar sağlayacaktır.

- Yükseköğretim kurumlarınca ve Din Öğretimi Genel Müdürlüğünce Arapça öğretimi ile ilgili hazırlanacak bilgilendirme materyalleri ile özellikle ilkokullarda bilgilendirmelerin yapılması zorunludur. Çünkü başta Arapçanın zor bir dil olduğu ve hayat boyu bireyin ihtiyaç duymayacağı ile ilgili yanlış ön yargıları ortadan kaldırmak bu şekilde mümkün olacaktır. Bu şekilde bir ön yargı neticesinde üzülerek müşahede ettiğimiz imam hatip ortaokullarındaki Arapça derslerinde verimin alınamamasının en büyük nedenlerinden biri bu olmaktadır. Çocuğunu imam hatip ortaokulu, lisesine gönderen velideki bu ön yargı sonucunda ne yazık ki bu okullarda İngilizce proje sınıflarına rağbet edildiği kadar Arapçaya proje sınıflarına rağbet edilmemektedir. Yine Arapça hazırlık sınıfları yıl kaybı olarak değerlendirilmekte ve LGS tercihlerinde Arapça hazırlık uygulayan imam hatip liseleri İngilizce hazırlık uygulayan liselere oranla daha az tercih edilmektedir.

- Liselerde bugün Arapçanın dil olarak seçilmemesinin en büyük nedenlerinden birinin de öğrenci ve velinin yeterli bir şekilde bilgilendirilmemesi olduğu açıktır. Öğrenci ve velilerin neredeyse tamamı liselerde Arapçanın dil olarak tercih edilebileceğini bilmemektedirler. $\mathrm{Bu}$ nedenle de gerekli bilgilendirmelerin yapılması önem arz etmektedir.

- Milli Eğitim Bakanlı̆̆ı mevzuatta yer verdiği Arapça eğitiminin liselerde verilmesi için uygulama düzeyinde gerekli düzenlemeleri yapması gerekmektedir. Bu düzenlemeler liselere Arapça öğretmeni norm kadrosu verilmesi, liseler için Anadolu İmam Hatip Liselerindeki müfredattan farklı bir müfredatın ve müfredatın uygulanacağı gerekli materyallerin hazırlanması vb. çalışmaları kapsamaktadır.

- Farklı türdeki liselerde yer verilen zorunlu ortak 2. Yabancı dil seçiminde uygulamadaki zorunlu Almanca seçiminden vazgeçilerek farklı dillere verilen öğrenci ve veliye seçme hakkının Arapça dersi içinde uygulanması gerekmektedir.

- Ülkemizde ortaöğretim öğrencileri yükseköğretim ile yükseköğretime geçiş sınavı sonrasında bir programa yerleştikten sonra tanışmaktadır. Bu durum yerleştiği bir programa uyum süreci ile karşılaşmasına bunun da çeşitli sorunlara neden olduğu görülmektedir. Her iki kurumumuzun yapacağı ortak çalışmalar ile yükseköğretimde Arapça öğretimi görmek isteyen öğrenciler başta olmak üzere özellikle ortaöğretim son sınıfta imkânlar ölçüsünde belli bir plan dâhilinde hazırlı sınıflarının derslerine katılmalarının sağlanmasının olumlu sonuçlar vereceği öngörülmektedir.

- Son yıllarda imam hatip liselerinde açılan Arapça proje okul ve sınıflarda yükseköğretim kurumlarındaki akademisyenlerden maksimum seviyede yararlanılmalıdır. Bu yaralanma karşılıklı bilgi alışverişinden, akademisyenlerin okulda ilmi toplantılar yapmalarına hatta imkânlar ölçüsünde bir kısım derslere girmesine kadar geniş bir yelpazede gerçekleşebilir.

- Arapça öğretiminde ortaöğretim kurumlarında uygulanan projelerin sürelerinin kısa olmasına dikkat edilmelidir. Projenin süresi uzun tutulduğunda olumlu sonuç almak zorlaşmaktadır. Çünkü projenin yapıldığı eğitim dönemindeki öğrenci grubunun içerisinde bulunduğu gelişim dönemi buna uygun değildir.

- Arapça hazırlık sınıfına yer veren imam hatip liselerinin Arapça öğretimi konusunda yükseköğretim kurumları ile ortaklaşa çalışmalar yapması büyük bir ihtiyaç ve zorunluluktur. Bununla ilgili yönetmelik düzenlemelerinin yapılması ile bu sınıflarda akademisyenlerin özellikle de öğrencilerin konuşma yeterliliğinin geliştirilmesi konusunda yabancı uyruklu akademisyen öğreticilerinin derslere girmesi sağlanmalıdır.

Adres

İstanbul Medeniyet Üniversitesi, Eğitim Bilimleri Fakültesi, Türkce ve Sosyal Bilimler Eğitimi Bölümü, Türkçe Eğitimi ABD Cevizli Kampüsü, Kartal-İstanbul/TÜRKIYE e-posta: editor@rumelide.com
Address

İstanbul Medeniyet University, Faculty of Education Sciences, Turkish and Social Scinces Education, Turkish Language Teaching Education, Cevizli Campus, Kartal-İstanbul /TURKEY e-mail: editor@rumelide.com 
- Yükseköğretim kurumlarında eğitim gören son sınıf öğrencileri, lisansüstü öğrencileri ile araştırma görevlilerine ortaöğretim kurumlarında çeşitli görevlerin verilmesi imam hatip liselerindeki Arapça öğretimine katkı sağlayacağı gibi, onların eğitiminde de büyük faydalar sağlayacağı düşünülmektedir.

- Yükseköğretim ve ortaöğretim kurumlarında yapılacak Arapça öğretimine ait projelere Milli Eğitim Bakanlığı ve Yükseköğretim Kurulu tarafından verilen desteklerin artırılması Arapça öğretiminde büyük katkılar sağlayacağı açıtır.

- Programda hedef davranış ve kazanımların ölçülmesinde uygulanan ve dilde dört temel beceriyi ölçmeyi sağlayan web tabanlı bir ölçme ve değerlendirme sisteminin kurumlarda kullanması fayda sağlayacaktır. Böyle bir sistem sayesinde öğrenme düzeyi hızlı bir şekilde tespit edilerek dönüt hemen gerçekleşecektir. Bu sistem sayesinde öğrenenin bireysel olarak dil becerisini artıracağına katkı sağlamasının yanında kurumlara zaman ve maliyet yönünden tasarruf sağlayacağı düşünülmektedir.

- Yükseköğretim Kurulunun eğitim fakültelerinde okutulan Arapça derslerine ait ders bazında belirlediği hedef-davranışların örnek alınarak, kurumların yönergelerinde belirledikleri genel amaçlarına ek olarak mutlaka ders bazında hedef-kazanımlarını belirlemeleri, programın çıtılları ve değerlendirme süreçlerine mutlaka yer vermeleri programın hedefine ulaşmasında yararlı olacăg görülmektedir.

- Dil öğretiminin sarmal bir yapıda önceki dönemi de içine alan bir süreç olduğu gerçeği unutulmaktadır. Arapça öğretimine ortaokul, lise ve yükseköğretimin sarmal bir yapıda aşamalılık ilkesi ile birbirini bütünlemesi gerekmektedir.

- Anadolu İmam Hatip Liseleri dışındaki ortaöğretim kurumlarında Arapça öğretimi için farklı bir program oluşturulmalıdır. Arapça öğretim programları oluşturulma süreçlerinde bütün eğitim dönemleri özellikle de ortaöğretim ve yükseköğretim birlikte ele alınarak program oluşturulmalıdır.

- İmam hatip liseleri ve yükseköğretim kurumlarının çoğunda Kuran-ı Kerim dersinin işleyişi daha çok yüzünden okuma şeklinde gerçekleşmektedir. Böyle bir işleyiş tarzı sonucunda da öğrenci Kuran-ı Kerim ve Arapça arasında bağlantı kuramamakta sonuçta Kuran ayetlerine anlam veremediği gibi yüzünden Kuran okurken öğrendiği Arapça basit terkip ve kuralların dahi farkında olmadığı görülmektedir. Bunun için de başta Kuran-ı Kerim dersleri olmak üzere diğer mesleki derslerin işlenişinde Arapçanın bu dersler için bir araç olduğu gerçeğinin öğrenci tarafından farkedilmesi sağlanmalıdır. Bu sıkıntı bazı İlahiyat fakültelerimizin Kuran-ı Kerim Okuma ve Kıraat Anabilim Dallarınca görülmüsş, öğrencilerin yüzünden okudukları sayfaların meallerinden de sorumlu tutuldukları bir sınav modeli geliştirilmiştir (Necmettin Erbakan Üniversitesi Ahmet Keleşoğlu İlahiyat Fakültesi).

- Fakülteler arası uzaktan eğitimlere yer verildiği gibi imam hatip liseleri kendi aralarında uzaktan eğitim verebilme imkanı tanınmalıdır. Ayrıca yükseköğretim kurumlarında verilen eğitimden uzaktan eğitim yoluyla ortaöğretim kurumlarının da faydalanması sağlanmalıdır.

- Arapça eğitimcileri öğrencileri Arapçanın kendilerine sağlayacağı avantajlar konusunda bilgilendirmelidir.

\section{Kaynakça}

Ankara Yıldırım Beyazıt Üniversitesi İnsan ve Toplum Bilimleri Fakültesi Mütercim-Tercümanlık (Arapça) Programı Zorunlu Arapça Hazırlık Sınıfı Programı Eğitim-Öğretim ve Sınav Yönergesi. (tarih yok). Ekim 16, 2020 tarihinde Ankara Ylldırım Beyazıt

Üniversitesi:https://aybu.edu.tr/insanvetoplum/dogudilleri/contents/files/haz\%c4\%b1rl\%c4\% b1k\%20y\%c3\%b6nergesi.pdf adresinden alındı

Artuklu Üniversitesi Arapça Hazırlık Sınıfı Programı Eğitim- Öğretim ve Sınav Yönergesi. (tarih yok). Eylül 15, 2020 tarihinde Artuklu Üniversitesi:

https://www.artuklu.edu.tr/dosyalar/arap_dili_edebiyati/Arapca\%20Haz\%C4\%B1rl\%C4\%B1k \%20Yo\%CC\%88nergesi_YENI\%CC\%87.pdf adresinden alındı

Coştu, K. (2016). Arapça Eğitiminde Öğrenmeyi Etkileyen Faktörler. BÜ. İslami İlimler Fakültesi Dergisi , 29.

Ekinci, İ. (2019). İlahiyat Fakültesi Öğrencilerine Verilen Arapça Hazırlık Eğitimine Dair Bir İnceleme. Van İlahiyat Dergisi , 144-161. 
The importance of individual works and cooperation of higher education and secondary education institutions in improving the quality of Arabic language teaching /M. Öztürk (pp. 898-914)

Karamanoğlu Mehmetbey Üniversitesi İslami İlimler Fakültesi Zorunlu Arapça Hazırlık Sınıfı EğitimÖğretim ve Sinav Yönergesi. (2016). Eylül 17, 2020 tarihinde Karamanoğlu Mehmetbey Üniversitesi: https://dosya.kmu.edu.tr/iif/userfiles/files/Y\%C3\%96NERGE.pdf adresinden alınd

Kömürcü, A. (2015). İlahiyat Fakültesi Hazırlık Sınıfı Öğrencilerinin Arapça Dersine İlişkin Tutumlarının İncelenmesi. Manisa Celal Bayar Üniversitesi Sosyal Bilimler Dergisi, , 119-140.

Kuran Okuma ve Tecvid Ders Müfredatı. (tarih yok). Ekim 8, 2020 tarihinde Necmettin Erbakan Üniversitesi Ahmet Keleşoğlu İlahiyat Fakültesi:

https://www.erbakan.edu.tr/ilahiyat/duyuru/18257/kuran-okuma-ve-tecvid-ders-mufredati adresinden alındı

Milli Eğitim Bakanlı̆̆ı Talim ve Terbiye Kurulu Başkanlığı. (2018). Ortaöğretim Kurumları Haftalk Ders Çizelgesi. Ankara: Talim ve Terbiye Kurulu Başkanlığı.

Milli Ĕgitim Bakanlığı Din Öğretimi Genel Müdürlüğ̈̈. (2018). Anadolu imam Hatip Lisesi Meslek Dersleri Programı. Ankara: Din Öğretimi Genel Müdürlüğü.

Muhammet Tasa, F. Z. (2012). Arapça Öğretiminde Web Tabanlı Bir Ölçme Değerlendirme Sistemi Geliştirilmesi. Marife , 9-24.

Necmettin Erbakan Üniversitesi Ahmet Keleşoğlu İlahiyat Fakültesi Zorunlu Arapça Hazırlık Sınıfı Ĕ̆itim- Öğretim ve Sinav Yönergesi. (2019). Eylül 17, 2020 tarihinde Necmettin Erbakan Üniversitesi:

https://www.erbakan.edu.tr/storage/images/department/ilahiyat/dosyalar/hazirlik_sinifi_yon ergesi.pdf adresinden alındı

Nevşehir Hacı Bektaş Veli Üniversitesi İlahiyat Fakültesi Zorunlu Arapça Hazırlık Sınıfı Uygulama Yönergesi. (tarih yok). Eylül 17, 2020 tarihinde Nevşehir Hacı Bektaş Veli Üniversitesi: https://ilahiyat.nevsehir.edu.tr/tr/hazirlik-arapca-yonergesi adresinden alındı

Resmi Gazete. (2016, Mart 23). Yükseköğretim Kurumlarında Yabancı Dil Öğretimi ve Yabancı Dille Öğretim Yapılmasında Uyulacak Esaslara İlişkin Yönetmelik .

Soyupek, H. (2008). Yabancı Dil Öğretimi Bağlamında Arapça Öğretiminde Motivasyonun Önemi. Süleyman Demirel Üniversitesi İlahiyat Fakültesi Dergisi , 186.

Yapıcı, Y. Ö.-A. (2016). İlahiyat Fakültesi Öğrencilerinin Arapça Dersine İlişkin Tutumlarının İncelenmesi (Ç.Ü. İlahiyat Fakültesi Örneği). Çukurova Üniversitesi İlahiyat Fakültesi Dergisi, 113-142.

Yükseköğretim Kurulu Arapça Öğretmenliği Lisans Programı. (tarih yok). Eylül 2020, 29 tarihinde Yükseköğretim Kurulu Başkanlığı:

https://www.yok.gov.tr/Documents/Kurumsal/egitim_ogretim_dairesi/Yeni-OgretmenYetistirme-Lisans-Programlari/Arapca_Ogretmenligi_Lisans_Programi.pdf adresinden alındı

\footnotetext{
Adres $\mid$ Address

İstanbul Medeniyet Üniversitesi, Eğitim Bilimleri Fakültesi, Türkçe İstanbul Medeniyet University, Faculty of Education Sciences, ve Sosyal Bilimler Eğitimi Bölümü, Türkce Eğitimi ABD Cevizli Turkish and Social Scinces Education, Turkish Language Teaching Kampüsü, Kartal-İstanbul/TÜRKIYE $\quad$ Education, Cevizli Campus, Kartal-İstanbul /TURKEY e-posta: editor@rumelide.com 1 e-mail: editor@rumelide.com
} 